\title{
Trends on Dermatology Research Published in the Journal of Pakistan Association of Dermatologists, Indian Journal of Dermatology, and Dermatology Research and Practice Journal from 2009 - 2019 \\ Zameer Hussain Baladi ${ }^{*}$, Tahira Yasmin² ${ }^{2}$ Iqra Dana ${ }^{3}$, Dr. Catharine Leo, MBBS $^{4}$
}

${ }^{1,2}$ Medical Librarians, King Saud Bin Abdulaziz University for Health Sciences, College of Applied Medical Sciences,Riyadh. Kingdom of Saudi Arabia

${ }^{3}$ Final year student, 2K60/Gen/54 Department of Genetics, University of Sindh Jamshoro, Pakistan

${ }^{4}$ Internee at Pondicherry Institute of Medical Sciences (PIMS), Pondicherry, India

Introduction: This study aimed to compare the research productivity published in three dermatological science research journals; Journal of Pakistan Association of Dermatologists. Indian Journal of Dermatology, and Dermatology Research and Practice from 2009 - 2019. Methodology: The published data downloaded from the websites of respective journals and the Scopus-Elsevier database in July 2020, and stored for numerical analysis in MS Excel sheet. Results: Total 3444 research papers written by 12723 authors with an average of $3.6 \%$, in eleven years JPAD published 870 articles contributed by 3118; $3.5 \%$ authors, IJD added huge amount 2285 of research written by 8259 authors, and 1346; $4.6 \%$ of authors associated with DRP present 289 manuscripts in dermatology discipline. Maximum 473 articles were published in 2015 by 1727; 3.6\% authors and 225 articles written by 727; $3.2 \%$ were submitted in 2009 as a minimum. Formation of author shows that the majority 3087; 89.6\% (JPAD 779; 89.5\%, IJD 2036; 89.1, and DRP 272; 94.1\%) of research conducted collaboratively. The combination of four author's popular form with participation in 824 articles. Solo or single authors appeared in 357; $10.3 \%$ articles. Conclusion: Indian Journal of Dermatology takes the lead and grab $66.3 \%$ of publications to $25 \%$ larger than Journal of Pakistan Association of Dermatologists, and Dermatology Research and Practice got $8 \%$ of publication share out of 3444 papers. New ideas, rapid availability of pathological results, intercommunications among researchers, advanced technological tools, and consistency in research presume to be a fact.

Keywords: Bibliometric, skin examination, dermatology, Pakistan, India, Egypt.

Copyright @ 2020: This is an open-access article distributed under the terms of the Creative Commons Attribution license which permits unrestricted use, distribution, and reproduction in any medium for non-commercial use (NonCommercial, or CC-BY-NC) provided the original author and source are credited.

\section{INTRODUCTION}

Dermatology is the sub-specialty of clinical medical and surgical sciences, which deals with the cure and prevention of diseases affiliated with body organs and influences fat, nails, hairs, and layers of body skin. It is specialized work done by a medical expert called dermatologists [1]. COVID- 19 pandemic prevents teachings, seminars, and lecture programs; it also hurt the community of dermatologists in participation with these. Dermatologists using technological help through teledermatology, and provide advice in inflammatory skin diseases with differential diagnosis [2]. The usage of Artificial intelligence (AI) is common in every discipline; in 2012, deep neural networks (DNN) software was created to recognize diseases through the image of skin [3]. Thomsen $\mathrm{K}$ et al. conducted a systematic review of malignant melanoma (MM) literature identified by the machine-learning tool published in the PubMed database. The study revealed 2175 publications indexed in a database that recognized eight main types' of dermatological diseases [4].

Bibliometric investigations of a single journal or comparing journals on the same disciplines are significant for distributors, researchers, institutes, pharmaceutical companies, and editors of the journals [5]. Cuocolo, L et al. explore the role of healthcare staff in magnetic resonance imaging (MRI) research focusing on the authorship pattern with discipline association. The study found 2053 articles, most of materials 2011; $52 \%$ written by cardiologists, radiologists, and nuclear medicine physicians as a second category [6]. Oh, Namkyung, and Junghyae Lee scrutinized the evaluation of communication, risk perception, and societal participation in the reduction of disaster losses in four decades and assured that the present development in emergency management connected with 
practical strategies, adapting new topics published in previous literature. They further explore that designing framework, establishing the system, and to deal with emerging challenges $[8,9]$.

Young, J.S., Turlington, A.G inquired about the status of pediatric research published in journals indexed in Web of Science (WoS) to identify the participation of authors affiliated with institutes working in Hawai'i. Total 989; 0.37\% records found out of 264064 documents, published under the umbrella of the United States (US) from 2000 - 2019. The study also found the different areas of research between Hawai' and the US.

The dominance of Asia-Pacific co-authorship, infectious diseases, medicine, immunology, and handling orthopedic emergencies got top slots [10, 11]. For supporting our study, Sab et al. conducted a bibliometric analysis on the Indian Journal of Marketing from 2013 - 2019, to identify the out-put of authors associated with high reputed organizations of India, significant trends in research topics, and significant changes in marketing strategies [12].

\section{MeTHODOLOGY}

This retrospective study aimed to compare the published data of three international electronic journals related to dermatological sciences, a sub-specialty of medicine and allied medicine; a) Journal of Pakistan Association of Dermatologists, b) Indian Journal of Dermatology, and c) Dermatology Research and Practice from 2009 - 2019. The records downloaded from the websites of respective journals and the ScopusElsevier database in July 2020 and stored for arithmetical analysis in MS Excel sheet, indexed in Scopus-Elsevier database. The objectives, a) to calculate year wise production, b) to analyze the participation of authors, $c$ ) to categorize the pattern of authorship, was set to investigate.

\section{RESULTS}

Figure 1 shows the whole picture of publications published in three journals JPAD, IJD, and EDRP, from 2009 - 2019. Table 1 explains the further breakdown of research productivity-total of 3444 articles written by $12723 ; 3.6 \%$ of authors. Journal of Pakistan Association of Dermatologists published 870 articles written by 3118 authors $3.5 \%$ per item, and 79 papers per annum, Indian Journal of Dermatology 2285 articles written by 8307 authors $3.6 \%$ per article and 207 articles per annum, and Dermatology Research and Practice 289 articles written by 1619 authors $5.6 \%$ per article and 26.2 articles per annum.

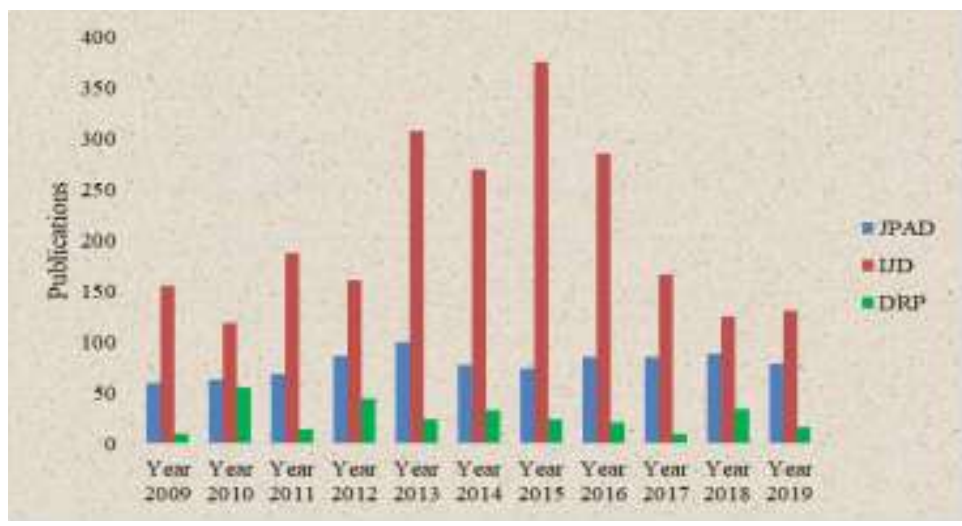

Fig-1: Research productivity published in three journals from 2009 - 2019

Table-1: Research articles published in the JPAD, IJD, and EDRP during the period of 2009 - 2019

\begin{tabular}{|r|r|r|r|r|r|r|r|r|r|}
\hline $\begin{array}{c}\text { S. } \\
\text { No }\end{array}$ & Years & $\begin{array}{c}\text { JPAD } \\
\text { Articles }\end{array}$ & $\begin{array}{c}\text { Total } \\
\text { authors } \\
\text { per } \\
\text { publication }\end{array}$ & $\begin{array}{c}\text { IJD } \\
\text { Articles }\end{array}$ & $\begin{array}{c}\text { Total } \\
\text { authors } \\
\text { per } \\
\text { publication }\end{array}$ & $\begin{array}{c}\text { DRP } \\
\text { Articles }\end{array}$ & $\begin{array}{c}\text { Total } \\
\text { authors } \\
\text { per } \\
\text { publication }\end{array}$ & $\begin{array}{c}\text { Total } \\
\text { Research }\end{array}$ & $\begin{array}{c}\text { Total } \\
\text { authors } \\
\text { with per } \\
\text { publication }\end{array}$ \\
\hline 1 & 2009 & 60 & $181(3)$ & 155 & $500(3.2)$ & 10 & $46(4.6)$ & 225 & $727(3.2)$ \\
\hline 2 & 2010 & 63 & $205(3.2)$ & 119 & $395(3.3)$ & 56 & $259(4.6)$ & 238 & $859(3.6)$ \\
\hline 3 & 2011 & 69 & $255(3.6)$ & 188 & $653(3.4)$ & 15 & $69(4.6)$ & 272 & $977(3.5)$ \\
\hline 4 & 2012 & 87 & $320(3.6)$ & 161 & $540(3.3)$ & 44 & $174(3.9)$ & 292 & $1034(3.5)$ \\
\hline 5 & 2013 & 100 & $366(3.6)$ & 308 & $1079(3.5)$ & 25 & $125(5)$ & 433 & $1570(3.6)$ \\
\hline 6 & 2014 & 78 & $275(3.5)$ & 270 & $967(3.5)$ & 33 & $146(4.4)$ & 381 & $1388(3.6)$ \\
\hline 7 & 2015 & 74 & $252(3.4)$ & 375 & $1369(3.6)$ & 24 & $106(4.4)$ & 473 & $1727(3.6)$ \\
\hline 8 & 2016 & 85 & $303(3.5)$ & 286 & $1032(3.6)$ & 21 & $75(3.5)$ & 392 & $1410(3.5)$ \\
\hline 9 & 2017 & 86 & $323(3.7)$ & 167 & $615(3.6)$ & 10 & $59(5.9)$ & 263 & $997(3.7)$ \\
\hline 10 & 2018 & 89 & $330(3)$. & 125 & $499(3.9)$ & 34 & $167(4.9)$ & 248 & $996(4)$ \\
\hline 11 & 2019 & 79 & $308(3.8)$ & 131 & $610(4.6)$ & 17 & $120(7)$ & 227 & $1038(4.5)$ \\
\hline & Total & 870 & $3118(3.5)$ & 2285 & $8259(3.6)$ & 289 & $1346(4.6)$ & 3444 & $12723(3.6)$ \\
\hline
\end{tabular}


Figure 2 explains the pattren of authorship, the majority 3087; 89.6\% (JPAD 779; 89.5\%, IJD 2036; 89.1 , and DRP $272 ; 94.1 \%$ ) out of 3444 articles written collaboratively. Maximum thirteen authors founds in two, and minimum single or solo author contributed in
357; 10.3 articles out of 3444 manuscripts. Four authors wrote $824 ; 24 \%$ articles, followed by thrre $718 ; 20.8 \%$, and two 577; $16.7 \%$ articles. The 313 articles published annualy (JPAD 79, IJD 207, and DRP 26) and 2.3 articles by monthaly.

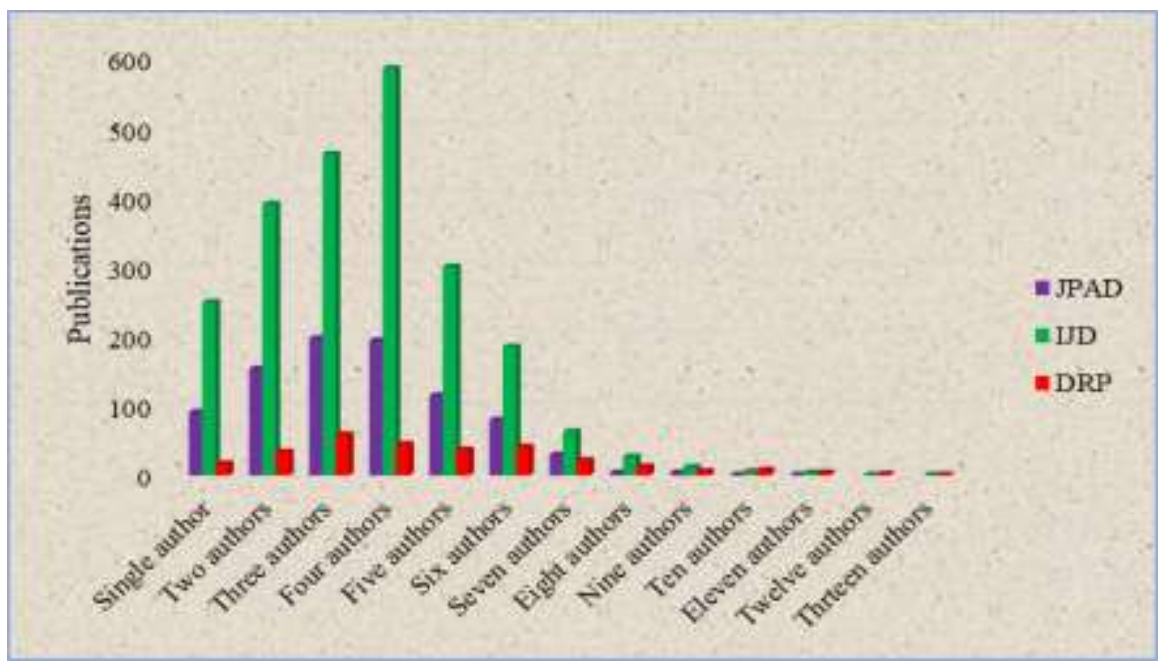

Fig-2: Authorship pattern

Table-2: Authorship Pattern of published articles in the JPAD, IJD, and EDRP during the period of 2009 - 2019

\begin{tabular}{|c|c|c|c|c|c|c|c|c|c|}
\hline $\begin{array}{l}\text { S. } \\
\text { No }\end{array}$ & $\begin{array}{l}\text { Pattern of } \\
\text { authorship }\end{array}$ & $\begin{array}{l}\text { JPAD } \\
\text { articles }\end{array}$ & $\begin{array}{l}\text { Figure } \\
\text { multiple by } \\
\text { pattern of } \\
\text { author }\end{array}$ & $\begin{array}{l}\text { IJD } \\
\text { articles }\end{array}$ & $\begin{array}{l}\text { Figure } \\
\text { multiple by } \\
\text { pattern of } \\
\text { author }\end{array}$ & $\begin{array}{l}\text { DRP } \\
\text { articles }\end{array}$ & $\begin{array}{l}\text { Figure } \\
\text { multiple by } \\
\text { pattern of } \\
\text { author }\end{array}$ & $\begin{array}{l}\text { Total } \\
\text { articles }\end{array}$ & $\begin{array}{l}\text { Total } \\
\text { figures } \\
\text { multiple } \\
\text { by pattern } \\
\text { of authors }\end{array}$ \\
\hline 1 & $\begin{array}{l}\text { Single } \\
\text { author }\end{array}$ & 91 & 91 & 249 & 249 & 17 & 17 & 357 & 357 \\
\hline 2 & $\begin{array}{l}\text { Two } \\
\text { authors }\end{array}$ & 153 & 306 & 390 & 780 & 34 & 68 & 577 & 1154 \\
\hline 3 & $\begin{array}{l}\text { Three } \\
\text { authors }\end{array}$ & 197 & 591 & 462 & 1386 & 59 & 177 & 718 & 2154 \\
\hline 4 & $\begin{array}{l}\begin{array}{l}\text { Four } \\
\text { authors }\end{array} \\
\end{array}$ & 194 & 776 & 585 & 2340 & 45 & 180 & 824 & 3296 \\
\hline 5 & $\begin{array}{l}\text { Five } \\
\text { authors }\end{array}$ & 115 & 575 & 300 & 1500 & 37 & 185 & 452 & 2260 \\
\hline 6 & Six authors & 80 & 480 & 185 & 1110 & 41 & 246 & 306 & 1836 \\
\hline 7 & $\begin{array}{l}\text { Seven } \\
\text { authors }\end{array}$ & 30 & 210 & 63 & 441 & 22 & 154 & 115 & 805 \\
\hline 8 & $\begin{array}{l}\text { Eight } \\
\text { authors }\end{array}$ & 4 & 32 & 27 & 216 & 13 & 104 & 44 & 352 \\
\hline 9 & $\begin{array}{l}\text { Nine } \\
\text { authors }\end{array}$ & 4 & 36 & 12 & 108 & 6 & 54 & 22 & 198 \\
\hline 10 & Ten authors & 1 & 10 & 6 & 60 & 8 & 80 & 15 & 150 \\
\hline 11 & $\begin{array}{l}\text { Eleven } \\
\text { authors }\end{array}$ & 1 & 11 & 4 & 44 & 4 & 44 & 9 & 99 \\
\hline 12 & $\begin{array}{l}\text { Twelve } \\
\text { authors }\end{array}$ & & 0 & 1 & 12 & 2 & 24 & 3 & 36 \\
\hline 13 & $\begin{array}{l}\text { Thirteen } \\
\text { authors }\end{array}$ & & 0 & 1 & 13 & 1 & 13 & 2 & 26 \\
\hline & & 870 & 3118 & 2285 & 8259 & 289 & 1346 & 3444 & 12723 \\
\hline
\end{tabular}

\section{Discussion \& CONCLUSION}

This study evaluates 3444 articles contributed by 12723 authors in the Journal of Pakistan Association of Dermatologists, Indian Journal of Dermatology, and Dermatology Research and Practice from $2009-2019$. JPAD published quarterly, IJD published bimonthly and
DRP regularly year wise. The year 2013 was most expensive for JPAD for posting 100 written by $366 ; 3.6$ authors and IJD 375 articles written by 1369; $3.6 \%$ authors in the year 2015 out of their total. DRP 44 articles published in 2012. The collaborative involvement of authors, constant approach of 
publications, sharing research ideas, usage of innovative equipment in diagnosis, and editorial policies of respective journals are factors in support to produce dermatology literature.

\section{AbBreViations}

JPAD: Journal of Pakistan Association of Dermatologists.

IJD: Indian Journal of Dermatology, and

DRP: Dermatology Research and Practice

\section{Disclaimer}

This examination presents just numbers and not slanted or declined development of any association, city, nation and guidelines.

\section{REFERENCES}

1. Burns T, Breathnach S, Cox N, Griffiths C, editors. Rook's textbook of dermatology. John Wiley \& Sons; 2008 Apr 15.

2. Wollina U. Challenges of COVID- 19 pandemic for dermatology. Dermatologic therapy. $2020 \mathrm{Apr}$ 20:e13430.

3. Dzobo K, Adotey S, Thomford NE, Dzobo W. Integrating artificial and human intelligence: a partnership for responsible innovation in biomedical engineering and medicine. OMICS: A Journal of Integrative Biology. 2020 May 1;24(5):247-63.

4. Thomsen K, Iversen L, Titlestad TL, Winther O. Systematic review of machine learning for diagnosis and prognosis in dermatology. Journal of Dermatological Treatment. 2020 Jul 3;31(5):496510.

5. Antia-Obong SE, Casselden B, Pickard A. A Bibliometric Analysis of Journal of Higher
Education Management (JHEM) from 2007 to 2016. Library Philosophy and Practice. 2019 Sep 16:3037.

6. Cuocolo R, Ponsiglione A, Dell'Aversana S, D’Acierno L, Lassandro G, Ugga L, Romeo V, Vola EA, Stanzione A, Verde F, Picariello V. The cardiac conundrum: a systematic review and bibliometric analysis of authorship in cardiac magnetic resonance imaging studies. Insights into imaging. 2020 Dec;11(1):1-8.

7. Baladi ZH. A pattern of research in coronaviruses in saudi arabia from 2014-2018. EUREKA: Social and Humanities. 2020 Aug 3(4):41-6.

8. Oh N, Lee J. Changing landscape of emergency management research: A systematic review with bibliometric analysis. International Journal of Disaster Risk Reduction. 2020 May 16:101658.

9. Son C, Sasangohar F, Neville T, Peres SC, Moon J. Investigating resilience in emergency management: An integrative review of literature. Applied Ergonomics. 2020 Sep 1;87:103114.

10. Young JS, Turlington AG. The State of Pediatric Research in Hawai ' $i$ : A Comparative Bibliometric Analysis. Hawai'i Journal of Health \& Social Welfare. 2020 May 1;79(5 Suppl 1):55.

11. Leon Guerrero RT, Palafox NA, Hattori-Uchima MP, Robinett HR, Vogel CW. Addressing Cancer Health Disparities in the Pacific Peoples of Hawai 'i, Guam, and the US Associated Pacific Islands Through Pacific-Focused Research Capacity Building. JCO Global Oncology. 2020 Jan;6:15560.

12. Sab MC, Kappi M, Bagalkoti V, Biradar BS. Indian Journal of Marketing: A Bibliometric Analysis. Indian Journal of Marketing. 2020 Apr 30;50(4):55-65. 